\title{
Tissue immunostaining for factor XIIla in dermal dendrocytes of pityriasis alba skin lesions ${ }^{*}$
}

\author{
Francisca Regina Oliveira Carneiro ${ }^{1}$ \\ Maiana Darwich Mendes ${ }^{1}$
}

\author{
Gabriela Borborema do Amaral ${ }^{1}$ \\ Juarez Antônio Simões Quaresma ${ }^{1}$
}

\begin{abstract}
BACKGROUND: Pityriasis alba affects 1\% of the world population and about $9.9 \%$ of the children in Brazil. However, its etiology remains uncertain.

OвJECTIVE: The objective of the present study was to evaluate the immunoexpression of factor XIIIa in dermal dendrocytes of skin lesions of pityriasis alba.

METHOD: Twenty patients with pityriasis alba and 20 patients with atopic dermatitis underwent biopsy. The dermal dendrocytes marked by factor XIIIa were counted by means of immunohistochemical analysis.

RESULTS: The mean amount of dermal dendrocytes found in the patients with pityriasis alba was 2, whereas in the patients with atopic dermatitis it was 4 , with a statistically significant difference between them. A cutoff point of 3 cells/square inch was established to differentiate pityriasis alba from atopic dermatitis, with $80 \%$ sensibility and $90 \%$ specificity.

CONCLUSION: We believe that pityriasis alba and atopic dermatitis should be considered different clinical forms within the spectrum of atopic disease, in which sun radiation plays an important role by modulating the progression of the disease. Keywords: Dermatitis, atopic; Factor XIIIa; Pityriasis
\end{abstract}

\section{INTRODUCTION}

Pigmentary skin lesions are among the most frequent dermatoses. Hypopigmentary lesions represent a large proportion of these dermatoses, and pityriasis alba (PA) is one of the most common types, affecting about $1 \%$ of the general population and approximately $9.9 \%$ of the children population. ${ }^{1-3}$

PA is a chronic, benign, inflammatory dermatosis. This skin condition has a high frequency of relapses, being characterized by anti-esthetic effects and unsuccessful treatment. Another characteristic of PA is the presence of irregular hypopigmented patches with well-defined borders and furfuraceous scales, ranging from 0.5 to $6 \mathrm{~cm}$ in diameter, preferably on the face, lateral portion of the arms, and trunk. ${ }^{4}$ This dermatosis affects people all over the world, and it is one of the most frequent skin conditions in childhood, especially in the age group between 6 and 16 years. ${ }^{5}$

As to its pathogenesis, the onset of PA lesions has been associated with environmental factors such as variations in temperature, relative air humidity, altitude, and excessive sun exposure. In addition, many authors have suggested that the main etiologic agent of PA is dry skin, which can be caused either by the wind in the winter and the sun in the summer. ${ }^{6} \mathrm{PA}$ is believed to be a healing residual post-inflammatory hypopigmentation, and most cases occur after sun exposure. ${ }^{6,7}$

Individual characteristics should also be highlighted, as PA is considered a minor symptom or diagnosis factor of atopic dermatitis (AD), which is characterized by chronic inflammation and itching. ${ }^{8,9}$ The prevalence of PA in individuals with atopic characteristics ranges from $32 \%$ to $34 \% .{ }^{10}$ There is also evidence of the relationship between PA and the presence of family and personal history of atopy, such as asthma, allergic rhinitis, and atopic eczema., ${ }^{2,11,12}$

Therefore, the relationship between PA and AD is extremely important. Some authors believe that PA is a healing $A D$, where there is regression of the inflammation, thus leading to hypomelanosis. ${ }^{13}$

In terms of immunohistochemical changes, PA pattern regarding the presence and amount of dendritic cells has not been well established. Dermal dendrocytes are dendritic cells derived from the bone marrow and found in the dermal conjunctive tissue. The coagulation factor XIIIa (FXIIIa) is a marker of dermal dendrocytes. Those cells are macrophages presenters of non-peptide antigens that are part of the monocyte-

\footnotetext{
Received on 15.10.2012

Approved by the Advisory Board and accepted for publication on 05.04.2013.

Study conducted at the Department of Dermatology of the Universidade do Estado do Pará (UEPA) - Belém (PA), Brazil.

Conflict of interest: None

Financial funding: None

Universidade do Estado do Pará (UEPA) - Belém (PA), Brazil
} 
macrophage system, which are CD1a negative and S100 protein negative ${ }^{14,15}$ Dermal dendrocytes are commonly found around the microvasculature, in the dermoepidermal junction, and around skin appendages. ${ }^{16}$

Dermal dendrocytes can be larger in inflammatory and tumor diseases. A larger number of dermal dendrocytes has been detected in chronic dermatoses such as contact eczema, atopic eczema, and psoriasis. ${ }^{17}$

\section{MATERIAL AND METHOD}

This was a non-interventional controlled, crosssectional, observational study based on the biopsy of skin lesions in two purposive samples: PA group ( $\mathrm{n}=$ 20 patients) and a control group consisting of patients with $\mathrm{AD}(\mathrm{n}=20$ patients). The number of participants was statistically estimated according to the frequency of patients with these diseases seen at our health care center. The collection of skin samples was conducted from June 2011 to June 2012. Later, the samples were analyzed using immunohistochemical examination.

Female and male patients diagnosed with AD or PA of all age groups and who accepted to participate in the study by signing the Informed Consent Form were included in our study. The study was conducted after being approved by the Research Ethics Committee.

The lesions undergoing biopsy were selected during the dermatological examination. In patients with PA, hypochromic spots that had not undergone any treatment before were selected.

In the control group, we selected lesions typical of atopic dermatitis, characterized by presence of erythema, vesicles, ulceration and crusting, which had not undergone any treatment as well.

Those patients who did not meet the criteria for diagnosis of PA or atopic dermatitis and patients who refused to participate were excluded from the study.

Those cells showing unequivocal brownish color on a bluish background due to staining with hematoxylin and those whose morphology was typical of dermal dendrocytes (fusiform) were considered to be "positive immunostaining". Next, dermal dendrocytes were counted, and their amounts were compared between the two groups (Figure 1).

In order to determine tissue immunostaining for factor XIIIa in dermal dendrocytes of skin lesions of PA and AD we used descriptive and inferential statistics. Quantitative variables were expressed as measures of central tendency and variation. The statistical inference for the quantitative variables was performed using Student's t test (Ayres et al, 2007, p.126) because the assumptions of homoscedasticity and normality were satisfied, according to the ShapiroWilk test (Ayres et al, 2007, p.206) (Figure 2). The cutoff point and the ROC curve (Receiver Operating
Characteristic Curve) were calculated (Figure 3). ${ }^{18}$ The alpha level to reject the null hypothesis was set 0.05 . The statistical analysis was performed using the computer program BioEstat version 5.2.

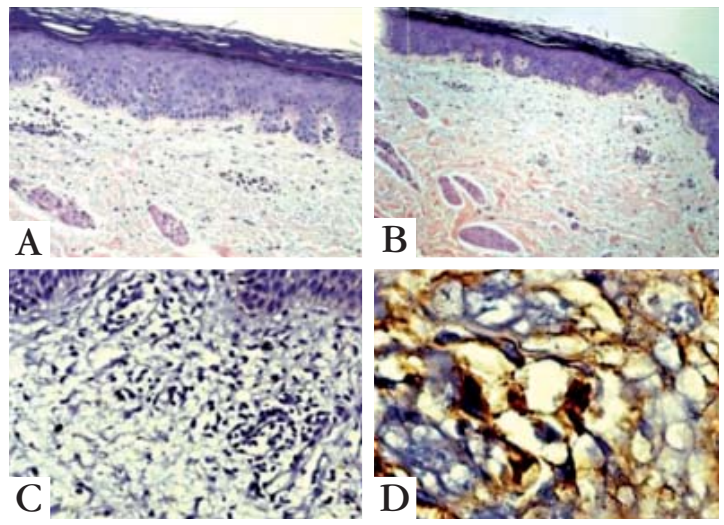

Source: Photos by the research team.

FiguRE 1: Histopathology and pattern of immunostaining for factor XIIIa. A - Histopathology of atopic dermatitis lesion. B Histopathology of pityriasis alba lesion. (A and $B=200 x$ ). C and D - Pattern of immunostaining for dermal dendrocytes in lesions of atopic dermatitis; $\mathrm{D}$ shows the fusiform morphology typical of these cells $(C=200 x, D=400 x)$

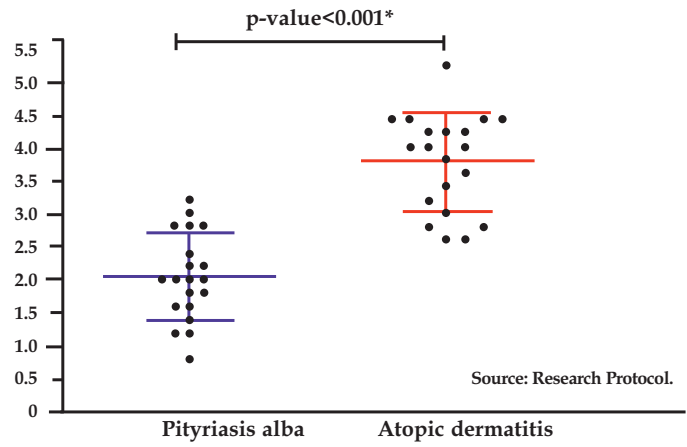

Figura 2: Mean and standard deviation cell count per field in patients with atopic dermatitis and pityriasis alba

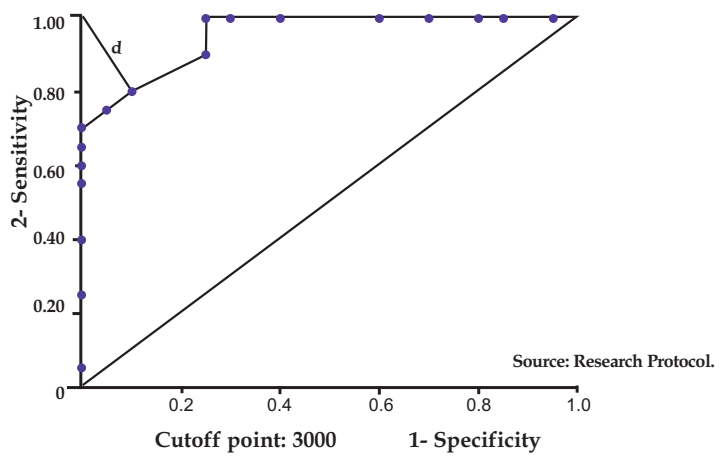

Figura 3: ROC curve (Receiver Operating Characteristic Curve) distinguishing between atopic dermatitis and pityriasis alba based on cell count per field 


\section{RESULTS}

The cutoff point for the amount of dermal dendrocytes that best differentiates PA from AD is the mean of 3 cells/field (Table 1). This value is statistically significant ( $\mathrm{p}$-value $<0.0001^{*}$ ) according to the Mann-Whitney test, showing sensitivity of $80 \%$ and specificity of $90 \%$.

TABLE 1: Mean number of cells per field in the skin samples of patients with atopic dermatitis and pityriasis alba. Department of Dermatology, Universidade do Estado do Pará from June 2011 to June 2012

\begin{tabular}{lll}
\hline & $\begin{array}{l}\text { Pityriasis } \\
\text { alba }\end{array}$ & $\begin{array}{l}\text { Atopic } \\
\text { dermatitis }\end{array}$ \\
\hline Arithmetic mean & 2.04 & 3.76 \\
Standard deviation & 0.65 & 0.73 \\
\hline
\end{tabular}

Source: Research Protocol.

$\mathrm{P}<0.0001$ (Student's $\mathrm{t}$ test)

\section{DISCUSSION}

After conducting the immunohistochemical study, we found that the mean amount of dermal dendrocytes in our sample showed a statistically significant difference between patients with PA and patients with AD.

This finding suggests that PA is an inflammatory dermatosis because of the presence of dermal dendrocytes. However, PA is less inflammatory than AD. A study has confirmed the inflammatory origin of PA based on the observation of its response to treatment with immunomodulators. This study compared the use of tacrolimus and placebo in children with PA and demonstrated higher levels of repigmentation in those patients who used tacrolimus. ${ }^{19}$

Therefore, PA cannot be considered a residual post-inflammatory manifestation because, if this was the case, a minimal amount of dendritic cells similar to the number found in normal skin would be expected..$^{20}$

On the other hand, if there was not a statistically significant difference in terms of amount of dermal dendrocytes between the two diseases, we could conclude that they are part of the same dermatosis.

Thus, a hypothesis has been raised that PA and $\mathrm{AD}$ are different clinical forms within the spectrum of atopy. A possible explanation may be that of a spectrum of atopic disease, in which a patient with history of atopic disease could develop both the AD pole (more inflammatory) or the PA pole (less inflammatory).

The same hypothesis was raised by researchers in northern Brazil. They stated that PA could not be form fruste of $\mathrm{AD}$, but instead another clinical form of the disease within the context of atopy. The same researchers found that $66 \%$ of patients with PA had a personal history of atopy. ${ }^{21}$

This hypothesis was also raised by researchers from Peru who believed that PA was a subtle manifestation of an atopic state whose most evident signs would be asthma, allergic rhinitis, and AD. ${ }^{22}$

At the same time that our findings suggest that there is inflammation in PA, even at a smaller scale, we disagree with many authors who believe that PA is a healing residual post-inflammatory hypopigmentation. ${ }^{6,723}$

Our hypothesis is in disagreement with several authors who claim that PA is a minor criterion or symptom of $\mathrm{AD}$, both being the same disease. ${ }^{1,24,5,5,6,9,24-26}$

Another fact observed in the present study shows a cutoff point of 3 cells (mean amount of dermal dendrocytes), which may differentiate between patients with PA and AD. This test showed $80 \%$ sensitivity and $90 \%$ specificity. Such data suggest the possibility of distinguishing between the two diseases based on an immunohistochemical analysis. Therefore, this may be an effective tool to study the pathogenesis of PA and AD, always combined with the clinical evaluation of patients.

Another hypothesis raised in this study was related to the real influence of sun exposure on the pathogenesis of PA. A possible hypothesis would be that when an atopic patient is exposed to ultraviolet radiation, it causes a localized immunosuppression, leading the patient to develop PA (less inflammatory) instead of developing AD (more inflammatory) ${ }^{27,28}$ Both dermatoses would be within the spectrum of atopy, but would be considered different clinical forms.

Considering the data revealed in the present study, we suggest that PA and AD are different clinical forms within the spectrum of atopic disease, in which radiation plays a key role by modulating the progression of the disease to the more or less inflammatory pole of the disease. This hypothesis suggests the possibility of new treatments for PA. However, further studies are needed to confirm this hypothesis.

\section{CONCLUSION}

The assessment of tissue immunoexpression for dermal dendrocyte marked by factor XIIIa in skin lesions of PA showed statistically significant differences in relation to $\mathrm{AD}$. This suggests that $\mathrm{PA}$ and $\mathrm{AD}$ are different clinical forms within the spectrum of atopic disease, in which sun radiation plays a key role by modulating the progression of the disease to the more or less inflammatory pole of the disease.

\section{ACKNOWLEDGEMENT}

The authors would like to thank the following people: Professor Francisca Regina Oliveira Carneiro, associate professor of the Universidade do Estado do 
Pará (UEPA) and coordinator of the Medical School of the UEPA, for sharing her knowledge and supporting us in face of difficulties, always stimulating us to move on.

Professor Juarez Antonio Simões Quaresma, associate professor of the UEPA, for allowing this dream to come true.

Professor Alena Margareth Darwich Mendes, assistant professor of the UEPA, for being our master. Professor Maria Amélia Lopes dos Santos, assistant professor of the UEPA, for her availability and affection.

Márcio, staff member of the Anatomy Laboratory, for helping us to accomplish this project.

The staff of the Outpatient Clinic of Dermatology for their support and patience.

And everyone who contributed, directly or indirectly, for the development of this research.

\title{
REFERENCES
}

1. Falabella R. Pigmentary disorders in Latin America. Dermatol Clin. 2007;25:419-30, X.

2. Weber MB, Ávila LGS, Cestari TF. Pitiríase Alba: aspectos epidemiológicos, clínicos e terapêuticos. An Bras Dermatol. 2000;75:359-67.

3. Harper J, Oranje A, Prose N. Harper's Textbook of pediatric dermatology. 3rd ed. Malden: Wiley Blackwell; 2011.

4. Azulay DR, Azulay RD. Dermatologia. 3. ed. Rio de Janeiro: Guanabara Koogan; 2004.

5. Nakamura RC. Pitiríase Alba: estudo clínico com correlação histopatológica em pacientes adultos. An Bras Dermatol. 2006; 81: 2

6. Blessmann Weber M, Sponchiado de Avila LG, Albaneze R, Magalhães de Oliveira OL, Sudhaus BD, Cestari TF. Pityriasis Alba: a study of pathogenic factors. J Eur Acad Dermatol Venereol. 2002;16:463-8.

7. Paller AS, Mancini AJ. Hurwitz dermatologia pediátrica: tratado de doenças da pele na infância e na adolescência. 3. ed. Rio de Janeiro: Revinter. 2009.

8. Hanifin JM, Raijka G. Diagnostic features of atopic dermatotis. Acta Derm Venereol. 1980; 92:44-7.

9. Jariwala SP, Abrams E, Benson A, Fodeman J, Zheng T. The role of thymic stromal lymphopoietin in the immunopathogenesis of atopic dermatitis. Clin Exp Allergy. 2011;41:1515-20.

10. Larralde M, Abad ME, Luna PC. Dermatología pediátrica. Buenos Aires: Ediciones Journal; 2010.

11. Uribe LHD. Pitiriasis Alba: aspectos epidemiológicos, clínicos y terapéuticos. MedUNAB. 2003;6:168-72.

12. Emedicine.com [homepage on the internet]. Crowe MA. Pityriasis Alba. [cited 2011 Mar 20]. Available from: http://www.emedicine.com/ped/topic1813.htm\#section author information.

13. Ramos-e-Silva M, Castro MCR. Fundamentos de Dermatologia. Rio de Janeiro: Atheneu; 2009.

14. Sueki H, Telegan B, Murphy GF. Computer-assisted three dimensional reconstruction of human dermal dendrocytes. J Invest Dermatol. 1995;105:704-8.

15. Kindt TJ, Goldsby RA, Osborne BA. Imunologia de Kuby. 6. ed. Porto Alegre: Artmed; 2008

16. Quatresooz P, Paquet P, Hermanns-Lê T, Piérard GE. Molecular mapping of factor XIllaenriched dendrocytes in the skin (reviem). Int J Mol Med. 2008;22:403-9.

17. Duarte ML, Rochael MC. Histopathological and immunohistochemical profile of the American cutaneous leishmaniasis with emphasis on FXIIla + dermal dendrocytes. An Bras Dermatol. 2006;81:541-44.

18. Ayres M, Ayres jr M, Ayres DL, Santos AS. BioEstat 5: Aplicações Estatísticas nas Áreas das Ciências Biológicas e Médicas. 5. ed. Belém: Publicações Avulsas do Mamirauá; 2007.

19. Rigopoulos D, Gregoriou S, Charissi C, Kontochristopoulos G, Kalogeromitros D, Georgala S. Tacrolimus ointment $0,1 \%$ in pityriasis alba: an open-label, randomized, placebo-controlled study. Br J Dermatol. 2006;155:152-5.

20. Soub CRW, Rochael MC, Cuzzi T. Granuloma Anular: distribuição tecidual dos dendrócitos dérmicos fator XIIla+, das células dérmicas trombomodulina+ e de macrófagos CD68+. An Bras Dermatol. 2003;78:289-98.

21. Carneiro FRO, Mendes AMD, Mendes MD, Amaral GB, Brito FCOCA, Ramos IR. Perfil clínico, epidemiológico e etiopatogênico da pitiríase alba em pacientes atendidos em um ambulatório de dermatologia no Norte do Brasil. In: Anais do 66 Congresso da Sociedade Brasileira de Dermatologia, 2011 set 3-6; Florianópolis. Sociedade Brasileira de Dermatologia: Florianópolis; 2011.

22. Barròn EN. Pitiriasis Alba: estudio prospectivo en 100 escolares del Callao. Lima; s.n; 1999.

23. Cestari SCP. Dermatologia pediátrica. São Paulo: Atheneu; 2012.

24. Hiletework M. Evaluation of hanifin and rajka eczema diagnostic guidelines for reduced minor criteria. Ethiop Med J. 2009;47:39-47.

25. Lin RL Janniger CK. Pityriasis Alba. Cutis. 2005;76:21-4.

26. Wahab MA, Rahman MH, Khondker L, Hawlader AR, Ali A, Hafiz MA, et al. Minor criteria for atopic dermatitis in children. Mymensingh Med J. 2011;20:419-24.

27. Norval $M$. The mechanisms and consequences of ultraviolet-induced immunosuppression. Prog Biophys Mol Biol. 2006;92:108-18.

28. Bechetoille N, Dezutter-Dambuyant C, Damour 0, André V, Orly I, Perrier E. Effects of solar ultraviolet radiation on engineered human skin equivalent containing both Langerhans cells and dermal dendritic cells. Tissue Eng. 2007;13:2667-79.

\author{
MAILING ADDRESS: \\ Francisca Regina Oliveira Carneiro \\ Rua Perebebuí, 2623 - Marco \\ 66087-670 - Belém - PA \\ Brazil \\ E-mail:reginacarneiro@globo.com
}

How to cite this article: Carneiro FRO, Amaral GB, Mendes MD, Quaresma JAS. Tissue immunostaining for factor XIIIa in dermal dendrocytes of pityriasis alba skin lesions. An Bras Dermatol. 2014;89(2):245-8. 